\title{
PENGARUH KEPEMIMPINAN, MOTIVASI, DAN PELATIHAN TERHADAP KINERJA KARYAWAN, STUDI PADA PT SURYA TOTO INDONESIA TBK. PLANT CIKUPA TANGERANG
}

\author{
Masruri \\ Universitas Islam Syekh Yusuf (UNIS) - Tangerang
}

\begin{abstract}
Employee performance can be traced back to the behavior of people in their working place in accordance with their role in the company. Performance assessment is carried out to provide information as a basis for decision making in an effort to improve the quality of company services. There are many factors that influence employee performance including leadership, work environment, work placement, career development, training, education, attendance, work culture and others. The study sought to establish the effect of leadership, motivation and training on employee performance in PT Surya Toto Indonesia Tbk both individually and jointly.

A survey method was applied using primary data obtained from the questionnaire. Population in this study was employees of PT. Surya Toto Indonesia Tbk plant Cikupa Tangerang. Sample size was 100 employees, consisted of permanent employee and contracted employee, using Stratified Random Sampling technique. Data quality was verified using validity test and reliability test. Data were analyzed using multiple linear regression, T-test, F-test, coefficient of determination, and classical assumption test.

The result of multiple linear regression analysis showed that leadership, motivation and training have positive influence to employee performance in PT Surya Toto Indonesia Tbk. This is indicated by positive regression coefficient numbers. It was also found that leadership, motivation and training have a significant effect to employee performance in PT Surya Toto Indonesia Tbk. indicated by the significance number generated in each variable below 0.05 from T-test and F-test. Based on the result of the coefficient of determination, the influence of leadership, motivation, and training variables on employee performance was $44.9 \%$ while the rest $(100 \%-44.9 \%=54.1 \%)$ was explained by other variables that were not used in this study.
\end{abstract}

Keywords: Leadership, Motivation, Training, Employee Performance

\begin{abstract}
ABSTRAK
Kinerja merupakan perilaku nyata yang ditampilkan seorang karyawan sebagai sebuah prestasi kerja sesuai dengan peranannya dalam perusahaan. Penilaian kinerja dilakukan untuk menyediakan informasi sebagai dasar pengambilan keputusan dalam upaya peningkatan kualitas layanan perusahaan. Ada banyak faktor yang mempengaruhi kinerja karyawan antara lain kepemimpinan, lingkungan kerja, penempatan kerja, pengembangan karir, pelatihan, pendidikan, kehadiran, budaya kerja dan lain-lain. Tujuan penelitian ini adalah untuk mengetahui pengaruh kepemimpinan, motivasi dan
\end{abstract}


pelatihan terhadap kinerja karyawan PT Surya Toto Indonesia Tbk baik secara individu maupun secara bersama-sama.

Penelitian ini menggunakan metode survei dengan menggunakan data primer yang diperoleh dari kuesioner. Populasi dalam penelitian ini adalah karyawan PT. Surya Toto Indonesia Tbk plant Cikupa Tangerang. Jumlah sampel yang diambil dalam penelitian ini adalah 100 orang karyawan. Sampel diambil dengan teknik Stratified Random Sampling (sampel bersumber dari karyawan strata karyawan tetap dan strata karyawan kontrak). Pengujian kualitas data menggunakan uji validitas dan uji reliabilitas. Data dianalisis dengan menggunakan analisis regresi linier berganda, uji T, uji F, uji koefisien determinasi, dan disertai dengan uji asumsi klasik.

Hasil analisis regresi linier berganda menunjukkan bahwa variabel kepemimpinan, motivasi dan pelatihan berpengaruh secara positif terhadap kinerja karyawan PT Surya Toto Indonesia Tbk., hal ini ditunjukkan oleh angka koefisien regresi yang positif. Hasil uji t menjelaskan bahwa variabel kepemimpinan, motivasi dan pelatihan secara individu berpengaruh signifikan terhadap kinerja karyawan PT Surya Toto Indonesia Tbk., hal ini ditunjukkan oleh angka signifikansi yang dihasilkan pada masing-masing variabel adalah di bawah 0,05. Hasil uji $\mathrm{F}$ menjelaskan bahwa variabel kepemimpinan, motivasi dan pelatihan secara bersama-sama berpengaruh signifikan terhadap kinerja karyawan PT Surya Toto Indonesia Tbk., hal ini ditunjukkan oleh angka signifikansi yang dihasilkan adalah di bawah 0,05. Berdasarkan hasil uji koefisien determinasi dapat dijelaskan bahwa pengaruh dari variabel kepemimpinan, motivasi, dan pelatihan terhadap kinerja karyawan adalah sebesar 44,9\% sedangkan sisanya $(100 \%-44,9 \%=54,1 \%)$ dijelaskan oleh variabel-variabel lain yang tidak digunakan dalam penelitian ini.

Kata kunci : Kepemimpinan, Motivasi dan Pelatihan terhadap Kinerja Karyawan

\section{BAB I \\ PENDAHULUAN}

\subsection{Kinerja Perusahaan}

Keramik adalah berbagai produk industri kimia yang dihasilkan dari pengolahan tambang seperti clay, feldspar, pasir silika dan kaolin melalui tahapan pembakaran dengan suhu tinggi. Industri keramik yaang terdiri dari ubin (tile), saniter, perangkat rumah tangga (tableware), genteng telah memberikan kontribusi signifikan dalam mendukung pembangunan nasional melalui penyediaan kebutuhan domestik, perolehan devisa dan penyerapan tenaga kerja. Hingga saat ini pemasaran industri keramik selain untuk memenuhi kebutuhan di dalam negeri juga telah diekspor ke berbagai negara seperti Asia, Amerika, Eropa (produk keramik tile dan saniter) dan keramik tableware ke negara-negara Amerika Serikat, Eropa, Asia, Afrika dan Amerika Latin. 
Krisis finansial yang melanda dunia sejak pertengahan tahun 2008 secara tidak langsung berdampak pada sektor industri keramik nasional dan permintaan dalam negeri ikut menurun sejalan dengan daya beli masyarakat yang lemah. Dalam kondisi perekonomian yang demikian maka produksi keramik yang berlebihan terutama dari China akan mencari pasar alternatif termasuk Indonesia sebagai pasar potensial mengingat pasar keramik dunia yang semakin terbatas, hal ini mengakibatkan industri keramik nasional menjadi tertekan dan seharusnya peluang pasar domestik yang menjadi andalan menjadi tertekan.

Tidak hanya sebatas pada tingginya tingkat persaingan usaha yang bersumber dari produsen keramik Cina, industri keramik Indonesia juga masih menghadapi banyak permasalahan yang bersumber dari dalam negeri. Permasalahan-permasalahan yang dihadapi oleh industri keramik tersebut diantaranya adalah: (a) pasokan gas alam yang digunakan sebagai bahan bakar keramik belum mendapat jaminan untuk jangka panjang; (b) harga gas alam ditetapkan dalam US Dollar, sehingga apabila nilai tukar rupaah melemah terhadap mata uang US dollar akan mengakibatkan naiknya harga pokok produksi; (c) industri pengolah bahan baku keramik sangat sedikit padahal beberapa daerah di Indonesia memiliki potensi bahan baku keramik, sehingga untuk bahan baku dengan kualitas tertentu masih banyak yang diimpor; (d) penguasaan research and development masih lemah; (e) sumber daya manusia (SDM) dibidang desain masih sangat lemah, adanya tuntutan Negara tujuan ekspor yang makin tinggi terutama masalah mutu dan desain; (f) persaingan terhadap produk keramik di pasar global baik di bidang kualitas maupun harga.

Sebagai salah satu produsen keramik, PT Surya Toto Indonesia Tbk juga merasakan pengaruh dari berbagai permasalahan di atas, yang dampaknya berpengaruh pada hasil penjualan dan laba kotor perusahaan. Data penjualan dan laba kotor PT Surya Toto Indonesia Tbk. secara lengkap dapat dilihat pada tabel 1.1 berikut ini. 
Tabel 1.1

Laporan Penjualan PT Surya Toto Indonesia Tbk. Periode 2007 - 2010

\begin{tabular}{|c|c|c|c|c|}
\hline Deskripsi & 2007 & 2008 & 2009 & 2010 \\
\hline $\begin{array}{l}\text { Penjualan } \\
\text { Bersih }\end{array}$ & $885,829,351,343$ & $1,124,346,781,952$ & $980,326,552,026$ & $1,121,498,803,607$ \\
\hline - Sanitary & $367,936,903,542$ & $460,334,621,634$ & $401,445,806,088$ & $582,411,191,640$ \\
\hline - Fittings & $467,671,749,712$ & $603,255,094,517$ & $551,036,442,726$ & $526,207,777,511$ \\
\hline $\begin{array}{lr}\quad- & \text { Kitchen } \\
\text { systems } & \text { dan } \\
\text { Marblite } & \\
\end{array}$ & $50,220,698,089$ & $60,757,065,801$ & $27,844,303,212$ & $12,879,834,456$ \\
\hline $\begin{array}{l}\quad \text { Beban } \\
\text { Pokok } \\
\text { Penjualan }\end{array}$ & $350,423,977,816$ & $816,674,603,138$ & $694,409,287,842$ & $774,226,999,137$ \\
\hline - Sanitary & $273,074,692,371$ & $345,671,086,433$ & $274,610,203,211$ & $399,161,217,876$ \\
\hline $\begin{array}{l}\text { - Fittings } \\
\text { - Kitchen }\end{array}$ & $339,516,363,881$ & $417,887,657,498$ & $386,791,317,493$ & $352,557,026,682$ \\
\hline $\begin{array}{l}\text { systems dan } \\
\text { Marblite }\end{array}$ & $43,397,651,564$ & $53,115,859,207$ & $33,007,767,138$ & $22,508,754,579$ \\
\hline Labar Kotor & $229,840,643,522$ & $307,672,178,824$ & $285,917,264,184$ & $347,271,804,500$ \\
\hline - Sanitary & $94,862,211,166$ & $114,663,535,211$ & $126,835,602,877$ & $183,249,973,764$ \\
\hline - Fittings & $128,155,385,831$ & $185,367,437,019$ & $164,245,125,233$ & $173,650,750,829$ \\
\hline $\begin{array}{lr}\quad-\quad & \text { Kitchen } \\
\text { systems } & \text { dan } \\
\text { Marblite } & \\
\end{array}$ & $6,823,046,525$ & $7,641,206,594$ & $(5,163,463,926)$ & $(9,628,920,093)$ \\
\hline
\end{tabular}

Sumber: Dioleh dari laporan keuangan tahunan yang diunduh di website Bursa Efek Jakarta periode $2007-2010$.

Berdasarkan tabel 1.1 dapat dijelaskan bahwa selama periode 2007 - 1010, kinerja penjualan bersih PT Surya Toto Indonesia Tbk. masih menunjukkan hasil yang fluktuatif. Pada 2008, penjualan bersih PT Surya Toto Indonesia Tbk mengalami kenaikan sebesar $27 \%$ jika dibandingkan dengan tahun sebelumnya. Kenaikan penjualan ini diikuti oleh kenaikan beban pokok penjualan sebesar $24 \%$, dan mampu menghasilkan kenaikan laba kotor sebesar 34\% jika dibandingkan dengan tahun sebelumnya.

Berbeda dengan tahun 2008, penjualan bersih pada tahun 2009 mengalami penurunan sebesar $13 \%$ jika dibandingkan dengan tahun sebelumnya. Penurunan penjualan ini tidak diikuti oleh penurunan beban pokok penjualan yang tinggi, penurunan yang terjadi hanya sebesar $15 \%$. Hal ini menyebabkan terjadinya penurunan laba kotor sebesar 7\% jika dibandingkan dengan tahun sebelumnya. 
Setelah mengalami penurunan pada tahun 2009, pada tahun 1010 penjualan bersih PT Surya Toto Indonesia Tbk. kembali mengalami kenaikan yaitu sebesar 14\% jika dibandingkan dengan tahun sebelumnya. Kenaikan penjualan ini diikuti oleh kenaikan beban pokok penjualan yang secara persentase masih di bawah kenaikan penjualan bersih, yaitu sebesar $11 \%$. Hal ini menghasilkan kenaikan laba kotor sebesar $21 \%$ jika dibandingkan dengan tahun sebelumnya.

Kenaikan laba kotor pada tahun 2010 masih terus berlanjut pada periode berikutnya. Pada kuartal I/2011, PT Surya Toto Indonesia Tbk menghasilkan kenaikan laba kotor sebesar $21,1 \%$ jika dibandingkan dengan perolehan periode yang sama. Kenaikan laba tersebut ditopang oleh kenaikan penjualan bersih sebesar 21,1\%.Beban pokok penjualan dilaporkan mengalami kenaikan sebesar 21,1\%. Hasil ini mengindikasikan keberhasilan PT Surya Toto Indonesia Tbk. untuk tetap mempertahankan kinerja perusahaan yang positif setelah mengalami penurunan penjualan bersih pada tahun 2009 .

Keberhasilan PT Surya Toto Indonesia Tbk. dipengaruhi oleh kinerja karyawan atau hasil kerja yang dicapai oleh seorang karyawan dalam melakukan tugas sesuai dengan tanggung jawab yang diberikan kepadanya. Kinerja karyawan dilakukan oleh segenap sumber daya manusia yang di PT Surya Toto Indonesia Tbk., baik unsur pimpinan maupun pekerja, yang secara langsung melibatkan faktor kepemimpinan, motivasi, dan pelatihan kerja karyawan.

Faktor kepemimpinan dapat memberikan pengaruh yang berarti terhadap kinerja karyawan, karena pimpinan yang merencanakan, menginformasikan, membuat dan mengevaluasi berbagai keputusan yang harus dilaksanakan dalam organisasi tersebut (Lewa dan Subowo, 2005). Martoyo (1988) dalam Lewa dan Subowo (2005) mengemukakan bahwa kepemimpinan merupakan faktor yang penting bagi sumbersumber dan alat-alat suatu organisasi. Faktor-faktor yang berhubungan dengan sikap, gaya, dan perilaku pimpinan sangat berpengaruh terhadap karyawan yang dipimpinnya bahkan turut berpengaruh terhadap kinerja organisasi.

Menurut Siagian (1995) dalam Lewa dan Subowo (2005) kepemimpinan merupakan ketrampilan dan kemampuan seseorang untuk mempengaruhi orang lain, melalui komunikasi baik langsung, maupun tidak langsung dengan maksud untuk menggerakkan orang-orang tersebut agar dengan penuh pengertian dan kesadaran bersedia mengikuti kehendak pemimpin tersebut. Pengaruh pemimpin dalam menjalankan tugasnya sangat penting. Dalam mencapai berbagai tujuan organisasi baik 
yang bersifat tujuan ekonomi, sosial atau politik sebagian besar tergantung kepada kemampuan para pemimpin dalam unit organisasi yang bersangkutan.

Kepemimpinan merupakan faktor penting dalam memberikan pengarahan kepada karyawan apalagi pada saat-saat sekarang ini di mana semua serba terbuka, maka kepemimpinan yang dibutuhkan adalah kepemimpinan yang bisa memberdayakan karyawannya. Kepemimpinan yang bisa menumbuhkan motivasi kerja karyawan adalah kepemimpinan yang bisa menumbuhkan rasa percaya diri para karyawan dalam menjalankan tugasnya masing-masing (Parlinda dan Wahyuddin, 2008).

Setiap pekerja mempunyai motivasi atau dorongan yang berbeda-beda agar mau bekerja dengan baik. Pada dasarnya setiap manusia bekerja didorong untuk memenuhi kebutuhannya. Motif bekerja dan tingkat kebutuhan para pekerja adalah tidak sama. Ada pekerja yang bekerja semata-mata untuk memperoleh penghasilan guna memenuhi kebutuhan fisiknya dan keluarganya, namun ada pula pekerja yang bekerja bukan hanya untuk memperoleh penghasilan, akan tetapi juga untuk mengejar prestasi atau penghargaan. Motivasi penting dalam usaha mendorong para pekerja agar bekerja dengan baik, namun pengertian motivasi sendiri banyak ditafsirkan secara berbeda-beda oleh para ahli sesuai dengan tempat dan keadaan masing-masing ahli tersebut.

Motivasi berhubungan erat dengan perilaku dan prestasi kerja, oleh karena itu perlu diarahkan guna mencapai tujuan organisasi. Dengan demikian motivasi dapat dipandang sebagai bagian integral manajemen personalia dalam rangka proses pembinaan, pengembangan dan pengarahan tenaga kerja, karena manusia merupakan unsur terpenting dan paling menentukan bagi kelancaran proses manajemen.

Pelatihan bagi karyawan merupakan sebuah proses mengajarkan pengetahuan dan keahlian tertentu serta sikap agar karyawan semakin terampil dan mampu melaksanakan tanggung jawabnya dengan semakin baik, sesuai dengan kapasitasnya masing-masing (Parlinda dan Wahyuddin, 2008). Pelatihan dimaksud untuk membantu meningkatkan kemampuan para karyawan melaksanakan tugas sekarang. Pelatihan merupakan bagian dari suatu proses pendidikan, yang tujuannya untuk meningkatkan kamampuan atau ketrampilan khusus seseorang atau kelompok orang (Notoatmodjo, 1998 dalam Sinay, 2009).

Melalui pelatihan ini para karyawan bisa terbantu mengerjakan pekerjaan yang ada dan dapat membuat tindakan atau usaha yang memadai secara berkesinambungan dalam rangka peningkatan efisiensi energi pada setiap langkah proses produksi. Melalui pelatihan diharapkan agar karyawan dapat melakukan berbagai upaya 
penghematan/peningkatan efisiensi dan dapat mengetahui dimana dan bagaimana tindakan peningkatan efisiensi energi tersebut perlu dilakukan. Peningkatan efisiensi penggunaan energi/bahan bakar dapat dilakukan dengan beberapa cara antara lain penggunaan peralatan produksi yang lebih baik, perbaikan ratio antara udara dan bahan bakar, peninggkatan penggunaan gas buangan, mereduksi kehilangan panas pada dinding tungku dan lain-lain.

Banyak penelitian-penelitian sebelumnya yang mencoba mengetahui pengaruh kepemimpinan, motivasi, dan pelatihan kerja terhadap kinerja karyawan. Studi yang dilakukan oleh Lewa dan Subowo (2005) menjelaskan bahwa kepemimpinan, lingkungan kerja, dan kompensasi secara parsial (individu) memiliki pengaruh positif dan signifikan terhadap kinerja karyawan. Kepemimpinan dapat ditingkatkan melalui beberapa cara, antara lain memperbaiki hubungan antara pemimpin dengan karyawannya, meningkatkan kemampuan pemimpin dalam memotivasi karyawannya agar bekerja dengan optimal, dan meningkatkan kemampuan pemimpin dalam memberi penghargaan kepada pekerja yang berprestasi.

Hasil penelitian Purnomo (2008) konsisten dengan hasil penelitian Lewa dan Subowo. Berdasarkan hasil uji statistik t, hanya variabel kepemimpinan saja yang secara parsial (individu) memiliki pengaruh yang signifikan terhadap kinerja karyawan, sedangkan variabel lainnya yaitu motivasi dan lingkungan kerja menunjukkan hasil yang tidak signifikan, walaupun jika diuji bersama-sama (uji statistik F) variabel kepemimpinan, motivasi kerja, dan lingkungan kerja secara bersama-sama berpengaruh secara signifikan terhadap kinerja karyawan.

Penelitian yang dilakukan Parlinda dan Wahyudin (2008) menjelaskan hasil yang berbeda dengan penelitian Purnomo. Hasil uji statistik t menjelaskan bahwa hanya variabel pelatihan dan lingkungan kerja saja yang secara parsial berpengaruh signifikan terhadap kinerja karyawan, sedangkan variabel kepemimpinan dan motivasi tidak memiliki pengaruh signifikan terhadap kinerja karyawan.

Studi yang dilakukan oleh Hidayat (2007) menunjukkan hasil yang berbeda dengan Parlinda dan Wahyudin. Hasil penelitian Hidayat menjelaskan adanya pengaruh yang signifikan antara variabel kinerja karyawan dengan prediktornya yaitu variabel motivasi kerja karyawan. Pengaruh yang ditunjukkan oleh koefisien regresi adalah positif, artinya motivasi kerja karyawan mempunyai pengaruh positif terhadap kinerja. Dengan adanya motivasi yang tepat para karyawan akan terdorong untuk berbuat semaksimal mungkin dalam melaksanakan tugasnya karena meyakini bahwa dengan 
keberhasilan organisasi dalam mencapai tujuan dan berbagai sasarannya, kepentingankepentingan pribadi para anggota organisasi tersebut akan tercakup pula. Dengan motivasi yang tinggi akan menciptakan sebuah komitmen terhadap apa yang menjadi tanggung jawabnya dalam menyelesaikan setiap pekerjaan.

Konsisten dengan penelitiannya Hidayat, studi yang dilakukan Soetjipto (2007) menjelaskan bahwa variabel pendidikan, pelatihan, motivasi, dan pengalaman kerja secara parsial berpengaruh signifikan terhadap kinerja karyawan. Motivasi kerja yang diberikan perusahaan akan mendorong karyawan untuk memberikan semua kemampuan yang dimilikinya secara maksimal dan bukan hanya kemampuan umum mendasar dari setiap pribadinya seperti halnya kemampuan intelektual dan fisik belaka. Untuk meningkatkan kemampuan para karyawan dalam melaksanakan tugasnya saat ini, perusahaan perlu melakukan pelatihan. Pelatihan merupakan setiap usaha untuk memperbaiki performance pekerja pada suatu pekerjaan tertentu yang sedang menjadi tanggung jawabnya, atau suatu pekerjaan yang ada hubungannya dengan pekerjaannya. Supaya efektif, pelatihan biasanya harus mencakup pengalaman belajar aktivitasaktivitas terencana dan didesain sebagai jawaban atau kebutuhan-kebutuhan yang berhasil diidentifikasikan.

Hasil studi yang dilakukan Darden dkk (2005) secara khusus menguji pelatihan terhadap produktivitas dan upah kerja, hasil penelitiannya menjelaskan bahwa Terdapat pengaruh signifikan antara pelatihan dengan produktivitas. Pengaruh pelatihan terhadap produktivitas lebih besar pengaruhnya jika dibandingkan dengan pengaruh pelatihan terhadap gaji. Peningkatan $1 \%$ pelatihan sama dengan kenaikan $6 \%$ produktivitas dan 3\% gaji. Darden dkk berargumentasi bahwa metologi yang terdapat pada literatur yang ada saat ini hanya fokus pada gaji dan telah melemahkan pentingnya pelatihan terhadap produktivitas. Fokus pada gaji hanya relevan pada pengukuran produktivitas tanpa memperhatikan manfaat produktivitas lain yang akan perusahaan dapatkan.

Berdasarkan latar belakang masalah yang sudah dijelaskan di atas, maka peneliti tertarik untuk menguji pengaruh kepemimpinan, motivasi, dan pelatihan terhadap kinerja karyawan, studi pada PT Surya Toto Indonesia Tbk. Plant Cikupa Tangerang.

\subsection{Metode Penelitiahan}

Metode penelitian yang digunakan dalam penelitian ini adalah pendekatan deskriptif dan asosiatif/hubungan. Penelitian deskriptif dilakukan untuk mengetahui nilai variabel mandiri, baik satu variabel atau lebih (independen) tanpa membuat 
perbandingan, atau menghubungkan dengan variabel yang lain Penelitian asosiatif merupakan penelitian yang bertujuan untuk mengetahui hubungan antara dua variabel atau lebih. Bentuk hubungan antara variabel dalam penelitian ini dijelaskan sebagai bentuk hubungan kausal atau hubungan sebab akibat.

Sumber data yang digunakan adalah data primer. Data primer adalah data yang diperoleh secara langsung dari sumbernya. Dalam penelitian ini data primer yang digunakan pemberian kuesioner kepada karryawan yang menyangkut variabel-variabel kepemimpinan, motivasi, dan pelatihan terhadap kinerja karyawan. Kuesioner atau angket merupakan teknik pengumpulan data yang dilakukan dengan cara memberikan seperangkat pertanyaan atau pernyataan tertulis kepada responden untuk dijawab (Sugiyono, 2015). Dalam teknik penelitian ini menggunakan kuesioner berupa daftar pertanyaan berisikan seluruh hal yang berkaitan dengan kepemimpinan, motivasi, dan pelatihan terhadap kinerja karyawan.

Berdasarkan data yang kami terima dari HRD, jumlah karyawan PT Surya Toto Indonesia Tbk. Plant Cikupa Tangerang pada Q1 2011 adalah sebesar 2.196 orang, yang terdiri atas 1.418 orang karyawan tetap dan 778 orang karyawan kontrak. Pada penelitian ini, jumlah sampel yang harus diambil meliputi strata status karyawan tetap dan karyawan kontrak. Dengan menggunakan rumus Slovin, maka jumlah sampel yang akan digunakan dalam penelitian ini adalah sebanyak 96 orang, kemudian dibulatkan menjadi 100 orang, dengan proporsi sebagai berikut:

- Karyawan tetap $=1.418 / 2.196 \times 100$ orang $=65$ orang.

- Karyawan kontrak $=778 / 2.196 \times 100$ orang $=35$ orang.

Analisis statistik yang digunakan dalam penelitian ini adalah analisis regresi linier berganda dengan menggunakan SPSS.

\section{BAB II}

\section{HASIL DAN PEMBAHASAN}

\section{1. Uji Regresi Linier Berganda}

Uji regresi linier berganda bertujuan untuk mengetahui seberapa besar pengaruh kepemimpinan, motivasi, dan pelatihan kerja terhadap kinerja karyawan. Hasil uji regresi linier berganda dapat dilihat pada tabel berikut ini. 
Tabel Hasil Uji Regresi Linier Berganda

\begin{tabular}{|cr|r|r|}
\hline \multirow{2}{*}{ Model } & & \multicolumn{2}{|c|}{ Unstandardized Coefficients } \\
\cline { 2 - 4 } & & B & \multicolumn{1}{c|}{ Std. Error } \\
\hline 1 & (Constant) & 9.618 & 2.580 \\
& Kepemimpinan & .162 & .068 \\
& Motivasi & .337 & .087 \\
& Pelatihan & .291 & .112 \\
\hline & &
\end{tabular}

Berdasarkan tabel di atas dapat diketahui bahwa masing-masing variabel independen (bebas) berpengaruh secara positif terhadap variabel terikatnya, atau dengan kata lain kepemimpinan, motivasi, dan pelatihan berpengaruh secara positif terhadap kinerja karyawan, hal ini ditunjukkan oleh nilai koefisien regresi (beta) yang positif. Berdasarkan nilai koefisien regresi, dapat dibentuk persamaan regresi sebagai berikut: Kinerja Karyawan $=0,9618+0,162$ Kepemimpinan + 0,337Motivasi + 0,291Pelatihan.

- Hasil uji regresi linier berganda menunjukkan bahwa variabel kepemimpinan memiliki pengaruh positif terhadap kinerja karyawan, hal ini dapat dilihat pada nilai koefisien regresi (beta) sebesar 0,162. Hal ini berarti semakin baik kepemimpinan maka semakin mempengaruhi peningkatan kinerja karyawan PT Surya Toto Indonesia Tbk.

- Hasil uji regresi linier berganda menunjukkan bahwa variabel motivasi memiliki pengaruh positif terhadap kinerja karyawan, hal ini dapat dilihat pada nilai koefisien regresi sebesar 0,337 . Hal ini berarti semakin baik motivasi karyawan, maka akan semakin mempengaruhi peningkatan kinerja karyawan PT Surya Toto Indonesia Tbk.

- Hasil uji regresi linier berganda menunjukkan bahwa variabel pelatihan kerja memiliki pengaruh positif terhadap kinerja karyawan, hal ini dapat dilihat pada nilai koefisien regresi sebesar 0,291. Hal ini berarti semakin baik pelatihan kerja karyawan maka akan semakin mempengaruhi peningkatan kinerja karyawan PT Surya Toto Indonesia Tbk.

- Berdasarkan nilai koefisien regresi yang dihasilkan pada masing-masing variabel bebas, dapat dijelaskan bahwa variabel motivasi memiliki pengaruh yang lebih besar jika dibandingkan dengan variabel kepemimpinan dan pelatihan. 


\subsection{Koefisien Determinasi}

Koefisien determinasi bertujuan untuk mengukur seberapa jauh kemampuan model dalam menerangkan variasi variabel dependen. Nilai koefisien determinasi yang kecil berarti kemampuan variabel-variabel independen dalam menjelaskan variasi variabel dependen amat terbatas. Hasil uji koefisien determinasi dapat dilihat pada tabel berikut ini.

Tabel Hasil Uji Koefisien Determinasi

\begin{tabular}{|r|r|r|r|}
\hline \multicolumn{1}{|r|}{ Mod } & $\mathrm{R}$ & R Square & Adjusted R Square \\
\hline 1 & $.683^{\mathrm{a}}$ & .466 & .449 \\
\hline
\end{tabular}

Sumber: Output SPSS.

Berdasarkan tabel di atas dapat diketahui bahwa nilai koefisien determinasi (Adjusted R Square) yang dihasilkan dalam penelitian ini adalah sebesar 0,449 atau sama dengan 44,9\%. Hal ini menjelaskan bahwa pengaruh dari variabel kepemimpinan, motivasi, dan pelatihan terhadap kinerja karyawan adalah sebesar 44,9\% sedangkan sisanya $(100 \%-44,9 \%=54,1 \%)$ dijelaskan oleh variabel-variabel lain yang tidak digunakan dalam penelitian ini.

Penelitian yang dilakukan oleh Lewa dan Subowo (2005) menemukan bahwa variabel lingkungan kerja dan kompensasi berpengaruh secara positif dan signifikan terhadap kinerja karyawan. Lingkungan kerja yang baik, aman, bersih dan sehat akan membuat karyawan merasa aman dan nyaman dalam melaksanakan tugas-tugas yang diberikan kepadanya. Lingkungan kerja lebih dititik beratkan pada keadaan fisik tempat kerja. Indikator-indikator lingkungan kerja meliputi ruangan, suhu udara maupun kebisingan. Dari pengertian tersebut maka lingkungan kerja dapat mempengaruhi kinerja karyawan dalam bekerja. Faktor kompensasi juga merupakan faktor yang mempengaruhi kinerja karyawan. Pemberian kompensasi yang makin baik akan mendorong karyawan untuk bekerja dengan baik dan produktif.

Penelitian yang dilakukan oleh Tampubolon (2007) membuktikan bahwa faktor etos kerja berpengaruh secara positif dan signifikan terhadap kinerja karyawan, walaupun masih memberikan kontribusi yang relatif kecil. Setiap organisasi yang selalu ingin maju, akan melibatkan anggotanya untuk meningkatkan mutu kinerjanya, 
diantaranya setiap organisasi harus memiliki etos kerja. Etos kerja yang tinggi biasanya muncul karena berbagai tantangan, harapan-harapan, dan kemungkinan-kemungkinan yang menarik. Situasi yang demikian dapat membuat manusia bekerja dengan rajin, teliti, berdedikasi, serta tanggung jawab yang besar.

Soetjipto (2007) menemukan bahwa pendidikan dan pengalaman kerja berpengaruh secara positif dan singnifikan terhadap kinerja karyawan. Pendidikan mempunyai fungsi sebagai penggerak sekaligus pemacu terhadap potensi kemampuan sumber daya manusia dalam meningkatkan prestasi kerjanya. Pendidikan dengan berbagai programnya mempunyai peranan penting dalam proses memperoleh dan meningkatkan kualitas kemampuan profesional individu. Melalui pendidikan seseorang dipersiapkan untuk memiliki bekal agar siap tahu, mengenal dan mengembangkan metode berpikir secar sistematik agar dapat memecahkan masalah yang akan dihadapi dalam pekerjaannya. Faktor pengalaman juga merupakan faktor yang mempengaruhi kinerja karyawan. Dengan pengalaman kerja akan lebih mudah melaksanakan pekerjaan. Semakin banyak pengalaman kerja seseorang maka akan semakin banyak manfaat yang berdampak pada luasnya wawasan pengetahuan di bidang pekerjaannya serta semakin meningkatkan keterampilan seseorang. Pengalaman kerja akan mempengaruhi keterampilan karyawan dalam melaksanakan tugas juga membuat kerja lebih efisien.

Selanjutnya, studi yang dilakukan oleh Widyatmini dan Hakim (2008) menemukan bahwa variabel kompetensi memiliki hubungan secara positif dan signifikan dengan kinerja karyawan. Kompetensi dapat dibentuk antara lain melalui pendidikan dan pelatihan agar dapat melaksanakan tugasnya sesuai standar yang diinginkan. Dengan kompetensi yang dimiliki oleh setiap pejabat pemerintah diharapkan tugas pemerintahan dapat berjalan dengan baik. Dengan kecakapan, kemampuan dan kewenangan yang dimilikinya maka masyarakat harus percaya dan berharap semua urusan mereka dapat dipenuhi.

Studi yang dilakukan oleh Amaral (2010) menemukan bahwa komitmen organisasi memiliki hubungan positif dan kuat dengan kinerja karyawan. Komitmen organisasi merupakan landasan yang penting dalam mengukur kinerja yang ada dalam suatu organisasi. Karyawan yang memiliki komitmen organisasi yang tinggi adalah karyawan yang lebih stabil dan lebih produktif sehingga pada akhirnya juga lebih menguntungkan bagi organisasi. Karyawan yang memiliki komitmen organisasi yang tinggi akan lebih termotivasi untuk hadir dalam organisasi dan berusaha mencapai tujuan organisasi. 


\subsection{Uji Hipotesis}

\section{a. Uji Hipotesis t}

Uji hipotesis t bertujuan untuk menguji pengaruh variabel kepemimpinan, motivasi, dan pelatihan secara individu terhadap kinerja karyawan. Untuk menguji apakah hipotesis yang diajukan diterima atau ditolak maka digunakan statistik t dengan tingkat kepercayaan adalah 95\% dan level pengujian yang digunakan $\alpha=5 \%$. Jika angka signifikansi > 0,05, maka variabel kepemimpinan, motivasi, dan pelatihan secara individu tidak memiliki pengaruh secara signifikan terhadap variabel kinerja karyawan. Sebaliknya jika angka signifikansi $<0,05$, variabel kepemimpinan, motivasi, dan pelatihan secara individu memiliki pengaruh secara signifikan terhadap variabel kinerja karyawan. Hasil uji hipotesis t dapat dilihat pada tabel berikut ini.

\begin{tabular}{|c|c|c|c|}
\hline \multicolumn{2}{|c|}{ Model } & \multirow{2}{*}{$\frac{\mathrm{t}}{3.727}$} & \multirow{2}{*}{$\frac{\text { Sig. }}{.000}$} \\
\hline 1 & (Constant) & & \\
\hline & Kepemimpinan & 2.387 & .019 \\
\hline & Motivasi & 3.865 & .000 \\
\hline & Pelatihan & 2.583 & .011 \\
\hline
\end{tabular}

Sumber: Output SPSS.

Berdasarkan tabel di atas, dapat diketahui bahwa variabel bebas (kepemimpinan, motivasi, dan pelatihan) secara individu memiliki angka signifikansi yang lebih kecil dari 0,05 , hal ini berarti variabel bebas (kepemimpinan, motivasi, dan pelatihan) secara individu memiliki pengaruh secara signifikan terhadap kinerja karyawan. Hasil ini mampu menjawab hipotesis penelitian yang menduga bahwa: (1) variabel kepemimpinan memiliki pengaruh secara signifikan terhadap kinerja karyawan, (2) variabel motivasi memiliki pengaruh secara signifikan terhadap kinerja karyawan, dan (3) variabel pelatihan memiliki pengaruh secara signifikan terhadap kinerja karyawan.

\section{b. Uji Statistik $\mathbf{F}$}

Uji hipotesis $\mathrm{F}$ bertujuan untuk menguji pengaruh variabel kepemimpinan, motivasi, dan pelatihan secara bersama-sama terhadap kinerja karyawan. Untuk menguji apakah hipotesis yang diajukan diterima atau ditolak maka digunakan statistik F dengan 
tingkat kepercayaan adalah 95\% dan level pengujian yang digunakan $\alpha=5 \%$. Jika angka signifikansi $>0,05$, maka variabel kepemimpinan, motivasi, dan pelatihan secara bersama-sama tidak memiliki pengaruh secara signifikan terhadap variabel kinerja karyawan. Sebaliknya jika angka signifikansi < 0,05, variabel kepemimpinan, motivasi, dan pelatihan secara bersama-sama memiliki pengaruh secara signifikan terhadap variabel kinerja karyawan. Hasil uji hipotesis $\mathrm{F}$ dapat dilihat pada tabel berikut ini.

Tabel Uji Hipotesis F

\begin{tabular}{|ll|r|r|}
\hline Model & & F & Sig. \\
\hline 1 & Regression & 27.918 & $.000^{\mathrm{a}}$ \\
& Residual & & \\
& Total & & \\
& & & \\
\hline
\end{tabular}

Sumber: Output SPSS.

Berdasarkan tabel di atas, dapat diketahui bahwa variabel bebas (kepemimpinan, motivasi, dan pelatihan) secara bersama-sama memiliki angka signifikansi sebesar 0,000 atau lebih kecil dari 0,05, hal ini berarti variabel bebas (kepemimpinan, motivasi, dan pelatihan) secara bersama-sama memiliki secara signifikan terhadap kinerja karyawan. Hasil ini mampu menjawab hipotesis penelitian yang menduga bahwa variabel kepemimpinan, motivasi, dan pelatihan secara bersama-sama memiliki pengaruh secara signifikan terhadap kinerja karyawan.

\section{BAB III \\ SIMPULAN}

1. Berdasarkan hasil analisis data dapat dijelaskan bahwa variabel kepemimpinan memiliki pengaruh secara positif dan signifikan terhadap kinerja karyawan, hal ini ditunjukkan oleh nilai koefisien regresi sebesar 0,162 dan angka signifikansi sebesar 0,019. Hal ini berarti semakin baik kepemimpinan yang ada di perusahaan maka akan semakin mempengaruhi peningkatkan kinerja karyawan PT Surya Toto Indonesia Tbk.

2. Berdasarkan hasil analisis data dapat dijelaskan bahwa variabel motivasi memiliki pengaruh secara positif dan signifikan terhadap kinerja karyawan, hal ini 
ditunjukkan oleh nilai koefisien regresi sebesar 0,337 dan angka signifikansi sebesar 0,000. Hal ini berarti semakin baik motivasi kerja karyawan maka akan semakin mempengaruhi peningkatan kinerja karyawan PT Surya Toto Indonesia Tbk.

3. Berdasarkan hasil analisis data dapat dijelaskan bahwa variabel pelatihan memiliki pengaruh secara positif dan signifikan terhadap kinerja karyawan, hal ini ditunjukkan oleh nilai koefisien regresi sebesar 0,291 dan angka signifikansi sebesar 0,011. Hal ini berarti semakin baik pelatihan kerja kayawan maka akan semakin mempengaruhi peningkatan kinerja karyawan PT Surya Toto Indonesia Tbk.

4. Berdasarkan nilai koefisien regresi yang dihasilkan pada masing-masing variabel bebas, dapat dijelaskan bahwa variabel motivasi memiliki pengaruh yang lebih besar jika dibandingkan dengan variabel kepemimpinan dan pelatihan.

5. Berdasarkan hasil analisis data dapat dijelaskan bahwa variabel kepemimpinan, motivasi, dan pelatihan secara bersama-sama berpengaruh secara positif dan signifikan terhadap kinerja karyawan, hal ini ditunjukkan oleh nilai F hitung sebesar 27,918 dan angka signifikansi sebesar 0,000.

6. Nilai koefisien determinasi (Adjusted R Square) yang dihasilkan adalah sebesar 0,449 atau sama dengan 44,9\%. Hal ini menjelaskan bahwa pengaruh dari variabel kepemimpinan, motivasi, dan pelatihan terhadap kinerja karyawan adalah sebesar $44,9 \%$ sedangkan sisanya $(100 \%-44,9 \%=54,1 \%)$ dijelaskan oleh variabel-variabel lain yang tidak digunakan dalam penelitian ini.

\section{DAFTAR PUSTAKA}

Darden, Lorraine, Howard Reed, dan John Van Reenen, 2005, The impact of training on productivity and wages: evidence from British panel data, The institute for fiscal studies.

Ghozali, Imam, 2009, Aplikasi Analisis Multivariate Dengan Program SPSS, Badan Penerbit Universitas Diponegoro, Semarang.

Griffin, Ricky W., 2005, Manajemen, Jilid 2, Erlangga, Jakarta.

Hidayat, 2007, Pengaruh motivasi kerja terhadap kinerja karyawan dengan variabel moderator etos kerja spiritual, Jurnal Ekonomi dan Manajemen, Vol. 8, No. 1, Februari 2007.

Ivancevich, John M., Robert Konopaske, Michael M. Matteson, 2007, Perilaku dan Manajemen Organisasi, Erlangga, Jakarta.

Kreitner, Robert dan Angelo Kinicki, 2005, Perilaku Organisasi, Salemba Empat, Jakarta. 
Lewa, Eka Idham Iip K, Subowo, 2005, Pengaruh Kepemimpinan, Lingkungan Kerja Fisik,d an Kompensasi Terhadap Kinerja Karyawan di PT Pertamina (Persero) Daerah Operasi Hulu Jawa Bagian Barat Cirebon, Jurnal Sinergi: Kajian Bisnis dan Manajemen, Jakarta.

Parlinda, Vera, M. Wahyuddin, 2008, Pengaruh Kepemimpinan, Motivasi, Pelatihan, dan Linkungan Kerja Terhadap Kinerja Karyawan Pada Perusahaan Daerah Air Minum Kota Surakarta, Program Pascasarjana Universitas Muhammadiyah Surakarta, Surakarta.

Purnomo, Joko, 2008, Pengaruh Kepemimpinan, Motivasi, dan Lingkungan Kerja Terhadap Kinerja Pegawai Negeri Sipil Pada Dinas Kehutanan dan Perkebunan Kabupaten Jepara, Jurnal Daya Saing, Jakarta.

Sinay, Philipus, 2009, Analisis faktor-faktor yang mempengaruhi kinerja karyawan pada PT BUMAKUMAWA Kota Sorong, Jurnal Analisis, Vol. 6, No. 2, September 2009.

Sofyandi, Herman, 2008, Manajemen Sumber Daya Manusia, Graha Ilmu, Yogyakarta.

Soetjipto, 2007, Pengaruh faktor pendidikan, pelatihan, motivasi dan pengalaman kerja terhadap kinerja kepada desa (studi pada kepala desa di Kecamatan Pakis dan Tumpang Malang), Jurnal Aplikasi Manajemen, Vol. 5, No. 1, April 2007.

Sugiyono, 2009, Metode Penelitian Bisnis, Alfabeta, Bandung.

Thoha, Miftah, 2009, Perilaku Organisasi: Konsep Dasar dan Aplikasinya, Raja Grafindo Persada, Jakarta.

Umar, Husien, 2002, Riset Pemasaran dan Perilaku Konsumen, Gramedia Pustaka Utama, Jakarta.

Rivai, Veithzal dan Deddy Mulyadi, 2010, Kepemimpinan dan Perilaku Organisasi, Raja Grafindo Persada, Jakarta.

Rivai, Veithzal, Ahmad Fawzi Mohd. Basri, Ella Jauvani Sagala, Silviana Murni, 2008, Performance Appraisal, Sistem yang tepat untuk menilai kinerja karyawan dan meningkatkan daya saing perusahaan, Raja Grafindo Persada, Jakarta.

Wibowo, 2009, Manajemen Kinerja, Raja Grafindo Persada, Jakarta.

Winardi, 2000, Kepemimpinan Dalam Manajemen, Rineka Cipta, Jakarta.

Winardi, 2008, Motivasi dan Pemotivasian Dalam Manajemen, Raja Grafindo Persada, Jakarta.

Roadmap Industri Keramik, 2009, Direktorat Jenderal Industri Agro dan Kimia, Departemen Perindustrian, Jakarta.

www.idx.co.id/laporan-keuangan-tahunan/PT-Surya-Toto-Indonesia-Tbk.

http://gresnews.com/ch/Economy/cl/Rp64/id/2071935/read/1/Surya-Toto-cetak-lababersih-Rp6474-miliar

William J. Stevenson, 2009, Management Operation. Prentice Hall. UK. 